Vol 1. No. 4, Oktober 2021 P-ISSN : 2774-8030, e-ISSN : 2774-8030

\title{
UPAYA OPTIMALISASI PENERAPAN NILAI-NILAI PANCASILA DALAM MENGHADAPI PANDEMI COVID-19 SEBUAH TINJAUAN LITERATUR
}

\author{
ENI LESTARI \\ SMKN 1 Cangkringan \\ email : enys.enlles@gmail.com
}

\begin{abstract}
ABSTRAK
Penelitian ini bertujuan untuk mengoptimalisasi penerapan nilai-nilai Pancasila dalam menghadapi pandemic covid-19. Jenis penelitian ini adalah deskriptif kualitatif. Pengumpulan data dilakukan dengan studi dokumentasi dan literatur. Hasil penelitian ini menunjukan, bahwa optimalisasi penerapan nilai-nilai Pancasila dalam mnghadapi pandemic covid-19 dapat diketahui dari (1) kemampuan mendisiplinkan seluruh perilaku warga, (2) mengedukasi atau mendidik warga untuk mematuhi protokol kesehatan yang ditetapkan Pemerintah, (3) mempersiapkan dan memenuhi kebutuhan hidup warga, (4) menanamkan kebiasaan pada warga untuk senantiasa mempraktikkan pola hidup sehat dengan berolahraga secara rutin dan teratur, (5) memelihara kesehatan mental warga, (6) saling memotivasi dan menguatkan, (7) sosial kemasyarakatan dalam upaya pemenuhan kebutuhan dasar manusia sebagai mahkluk sosial.
\end{abstract}

Kata Kunci: nilai-nilai Pancasila, pandemic covid-19, kajian literatur

\section{PENDAHULUAN}

Pada saat ini dunia sedang mengalami fenomena yang luar biasa tak terkecuali negeri kita Indonesia, fenomena tersebut adalah pandemi corona virus (Covid-19). Wabah tersebut memberikan dampak ke seluruh sektor dan sendi kehidupan. Covid-19 atau disebut Coronavirus Disease 2019 merupakan penyakit menular yang dapat menyebabkan penyakit paru-paru yang cukup serius. Kasus Covid-19 ditemukan pertama kali di Tiongkok pada November 2019. Covid-19 diketahui sebagai penyakit menular yang disebabkan oleh virus baru dengan tingkat persebaran sangat cepat (Sumadi, 2020).

Fenomena wabah sejatinya telah terjadi berulangkali sepanjang sejarah pada umat manusia (Butar-butar, 2020: 10). Sampel yang diperiksa termasuk ke dalam etiologi coronavirus baru. Awalnya virus ini dinamakan novel coronavirus (2019-nCoV), kemudian WHO mengumumkan nama yang baru yakni Coronavirus Disease (COVID-19) yang disebabkan oleh virus Severe Acute Respiratory Syndrome Coronavirus-2 (SARS-CoV-2). 4 Virus ini mulai menyebar keseluruh dunia tak terkecuali Indonesia.

Tidak berbeda jauh dengan kondisi di negara lain, melonjaknya angka penularan Covid19 juga terjadi di Indonesia. Bila dirunut kembali ke belakang, sejak pertama kali ditemukannya dua kasus warga Indonesia yang terpapar Covid 19, hingga per 10 Juni 2020 jumlah penderita Covid-19 yang terkomfirmasi positif tidak kurang dari 42.762 orang dengan rincian 16.798 sembuh dan 2339 meninggal dunia (JNN, n.d.). Kecenderungan meningkatnya infeksi Covid19 di Indonesia tidak hanya berdampak buruk pada masalah kesehatan, tetapi juga berpengaruh dan berimplikasi negatif terhadap bidang kehidupan lainnya, seperti ekonomi, pendidikan, agama, dan sosial budaya. Misalnya dampak Covid-19 terhadap perekonomian Indonesia, yaitu adanya kebijakan efisiansi produksi perusahaan yang disusul dengan terjadinya gelombang PHK besarbesaran, sehingga melahirkan jutaan pengangguran. Ini juga memicu kekhawatiran akan terjadinya krisis ekonomi dan resesi (Abdi, 2020). Tidak lama, daya beli masyarakat pun ikut merosot yang membuatnya kesulitan dalam memenuhi kebutuhan hidup. Di masa pandemi Covid19 ini semakin banyak orang yang frustasi atau stres menghadapi memburuknya situasi dan kondisi perekonomian (Ichino, et al., 2020). Akibat Covid-19 pendidikan pun berubah paradigma, berhubung aktivitas pembelajaran bergeser dari lingkungan sekolah yang sebelumnya berbasis tatap muka (klasikal) menjadi virtual (dunia maya) (Almarzooq, et al., 2020). Diharapkan dengan penutupan sekolah selama pandemi dapat memutus rantai penularan. Selain meniadakan kegiatan pendidikan di sekolah, Covid-19 juga mengganggu kegiatan sosial, 
budaya, dan keagamaan. Penularan Covid-19 melalui kontak fisik juga menghalangi manusia dalam mengaktualisasikan dirinya sebagai mahkluk sosial untuk berinteraksi (Montironi, et al., 2020).

Fenomena virus ini praktis mempengaruhi seluruh sendi kehidupan manusia, baik mulai dari kebiasaan, kemampuan, dan bahkan sisi kemanusiaan. Mewabahnya covid-19 yang begitu massive tentu menghasilkan korban yang tidak sedikit. Kengerian yang ditunjukkan oleh virus ini menjadikan momok yang begitu menakutkan bagi setiap manusia. Adanya fakta bahwa covid-19 menular begitu cepat membuat setiap orang bagitu dilanda ketakutan untuk bersentuhan dengan orang lain, bahkan sekalipun kepada mayat covid-19. adanya beberapa yang masih menolak penguburan positif Covid-19 karena dalih ketakutan secara berlebihan dengan virus tersebut. Hal ini tentu saja mengancam kemanusiaan yang diajarkan oleh Pancasila (Sari \& Wahid, 2020).

Untuk menanggulangi implikasi destruktif pandemi Covid-19, Pemerintah dengan sigap mengambil langkah-langkah strategis. Di bidang kesehatan, langkah-langkah yang dilakukan oleh pemerintah untuk menangani kasus luar biasa ini salah satunya adalah dengan mensosialisasikan gerakan social distancing (Putri, 2020). Pemerintah Indonesia telah melakukan banyak langkah-langkah dan kebijakan untuk mengatasi permasalahan pandemic ini. Salah satu langkah awal yang dilakukan oleh pemerintah yaitu mensosialisasikan gerakan Social Distancing untuk masyarakat. Langkah ini bertujuan untuk memutus mata rantai penularan pandemi covid-19 ini karena langkah tersebut mengharuskan masyarakat menjaga jarak aman dengan manusia lainnya minimal 2 meter, tidak melakukan kontak langsung dengan orang lain serta menghindari pertemuan massal (Buana, 2020). Selain itu, Pemerintah juga mengkampanyekan dan menggencarkan penggunaan masker di ruang publik, penelusuran kontak (tracing) dari kasus positif yang tengah dirawat, mendorong isolasi mandiri, dan isolasi rumah sakit (Tuwu, 2020). Sedangkan peran Pemerintah dibidang ekonomi, yaitu memerintahkan kepada kepala daerah untuk memangkas rencana belanja yang bukan prioritas dalam APBD dan mengalokasikan ulang anggarannya guna mempercepat pengentasan dampak ekonomi akibat pandemi Covid-19 (Pratiwi, 2020).

Pemerintah berupaya menjamin ketersediaan kebutuhan pokok yang diikuti dengan memastikan terjaganya daya beli masyarakat. Program padat karya diperbanyak dan dilipat gandakan jumlahnya namun dengan tetap memperhatikan protokol kesehatan. Melalui kebijakannya, Pemerintah Pusat memberikan tambahan sebesar lima puluh ribu kepada pemegang kartu sembako murah selama enam bulan. Mempercepat implementasi kartu prakerja guna mengantisipasi pekerja yang terkena PHK, pekerja kehilangan penghasilan, dan pengusaha mikro yang kehilangan pasar dan omzetnya. Pemerintah juga membayarkan pajak penghasilan (PPh) Pasal 21 yang selama ini dibayar oleh wajib pajak (WP) karyawan di industri pengolahan. Otoritas Jasa Keuangan (OJK) memberikan relaksasi kredit di bawah sepuluh miliar untuk Usaha Mikro Kecil dan Menengah (UMKM). Masyarakat berpenghasilan rendah yang melakukan kredit kepemilikan rumah bersubsidi, akan diberikan stimulus. Di samping itu, Pemerintah membuat kebijakan yang memberikan subsidi listrik bagi masyarakat yang kurang mampu (Kurniawansyah, dkk, 2020).

Berbagai kebijakan Pemerintah tersebut cukup membuktikan, bahwa permasalahan Covid-19 ini membutuhkan perhatian, penanganan serius, dan kerjasama yang solid dari seluruh elemen bangsa Indonesia. Sayangnya selama ini hanya Pemerintah yang berperan menghadapi peliknya problematika Covid-19. Padahal mustahil membebankan persoalan Covid-19 kepada Pemerintah saja. Karena itu sudah sewajarnya bukan cuma pemerintah yang bergerak dalam me pandemi COVID-19 di Indonesia, tetapi juga lapisan masyarakat sipil (Mulyadi, 2020). Menghadapi Covid-19 yang melibatkan partisipasi masyarakat sipil dapat dimulai dari unit terkecilnya, yaitu warga. Mengingat sebagai strukttur sosial terkecil, Rukun Warga merupakan miniatur masyarakat yang kompleks (Santika, 2019). Artinya Rukun Warga ialah institusi terkecil dari suatu masyarakat yang memiliki struktur sosial dan sistem tersendiri...” (Aziz, 2017). Partisipasi masyarakat dalam penanganan Covid-19 mempunyai 
peran yang sangat penting, masyarakat dapat berperan bukan saja sebagai objek tetapi juga sebagai subjek penanganan Covid-19. Partisipasi masyarakat pada dasarnya merupakan kesediaan secara ikhlas dari masyarakat untuk membantu kegiatan penanganan penyakit yang terjadi di daerahnya masing-masing agar penyebaran 14 Covid-19 ini tidak semakin meluas. Sebagai unit terkecil dari masyarakat, Rukun Warga sebenarnya memiliki peran strategis dalam menghadapi Covid-19. Rukun Warga pada situasi seperti ini adalah sebagai sistem pertahanan pertama dan utama bagi negara dalam mencegah meluasnya penularan Covid-19. Peran yang melekat pada Rukun Warga itulah yang perlu dioptimalkan sebagai strategi preventif dalam menghadapi Covid-19. Bila setiap Rukun Warga di Indonesia benar-benar memainkan perannya secara optimal, niscaya kerja keras Pemerintah dalam menanggulangi Covid-19 tidak akan sia-sia. Dengan demikian, upaya pemerintah dalam mencegah penularan Covid-19 dapat dimulai dari unit terkecil masyarakat, yakni Rukun Warga. Dalam penanganan penyebaran virus Covid-19, masyarakat tidak lagi sebagai "penonton" dan menyerahkan semua urusan tersebut pada pemerintah, tetapi diharapkan masyarakat aktif terlibat dalam penanganan virus tersebut. Peran serta masyarakat perlu ditumbuhkan dalam setiap kegiatan, masyarakat harus menyadari bahwa penanganan virus ini merupakan tugas bersama. Keterlibatan masyarakat dengan mental dan emosi adalah wujud partisipasi sukarela tidak dengan paksaan atau mobilisasi. Masyarakat diharapkan menjadi mitra pemerintah dalam penanganan virus tersebut (Sari, 2020).

\section{METODE PENELITIAN}

Metode penelitian yang digunakan dalam penelitian ini adalah deskriptif kualitatif. Penelitian deskriptif kualitatif berusaha menggambarkan suatu gejala sosial yang tertuju pada pemecahan masalah di masa sekarang dan mendatang (Santika, 2019). Gaya penelitian kualitatif berusaha mengkonstruksi realitas dan memahami maknanya. Penelitian deskriptif kualitatif ditujukan untuk mendeskripsikan dan menggambarkan fenomena-fenomena yang ada, baik bersifat alamiah maupun rekayasa manusia, yang lebih memperhatikan mengenai karakteristik, kualitas, keterkaitan antar kegiatan (Sukmadinata, 2011). Gejala sosial atau fenomena dalam penelitian ini adalah pandemi Covid-19 di Indonesia yang berpengaruh besar terhadap peran institusi sosial antar warga. Teknik pengumpulan data dalam penelitian kualitatif secara umum terdiri dari empat macam, yaitu observasi, wawancara, dokumentasi, dan gabungan atau triangulasi (Sugiyono, 2015). Dalam penelitian ini, metode pengumpulan data yang digunakan adalah studi dokumentasi dan literatur. Studi literatur yang dilakukan dengan mencari berbagai sumber tertulis, baik berupa buku-buku, arsip, majalah, artikel, dan jurnal, serta dokumen-dokumen yang dapat membantu peneliti dalam optimalisasi peran warga dalam menghadapi persoalan Covid-19.

\section{HASIL DAN PEMBAHASAN}

Dimasa pandemi Covid-19, masyarakat telah membuktikan ketangguhannya dalam membentengi dan melindungi semua anggotanya dari bahaya penularan virus tersebut. Mewabahnya Covid-19 di pelbagai belahan negara menjadi bukti empiris bagaimana vitalnya peran warga sebagai tempat berlindung paling aman supaya terhindar dari infeksi Covid-19. Secara terbuka Pemerintah pun tidak malu mengakui strategisnya peran warga dalam upaya membendung, melokalisir, dan memutus mata rantai penyebaran Covid-19 di Indonesia. Pengakuan eksplisit negara atas besarnya kontribusi warga dalam mencegah dan menghentikan penularan Covid-19 diwujudkan melalui kebijakan dan himbauan Pemerintah yang membatasi warganya beraktivitas di luar rumah. Psycal distancing or social distancing adalah salah satu dari sekian derat himbauan Pemerintah untuk melindungi warganya agar tidak terjangkit Covid19. Disamping itu, Pemerintah juga mengambil kebijakan deliberatif lainnya, seperti mengalih fungsikan rumah yang tadinya hanya berurusan dengan problematika warga, kemudian berubah menjadi pusat dari segala kegiatan warganya. Mencermati fenomena perubahan fungsi rumah akibat Covid-19, menyiratkan adanya pergeseran peran warga yang sebelumnya hanya 
dipandang sebelah mata kini menjadi paling utama. Dalam waktu yang belum dapat diprediksi, peran warga tampaknya semakin strategis dan fungsional seiring dengan angka penularan Covid-19 di Indonesia yang masih tinggi. Terlebih lagi hingga detik ini belum juga ditemukan vaksin yang mampu menyembuhkan pasien Covid-19. Dengan demikian, haruslah diakui, bahwa warga merupakan garda terdepan yang menjadi subsistem fundamental yang paling diperhitungkan Pemerintah dalam memutus mata rantai penularan Covid-19.

Peran warga semakin instrumental dalam kehidupan berbangsa dan bernegara (Santika, 2020). Lebih-lebih ditengah melonjaknya angka kasus penularan Covid-19, Pemerintah justru berencana memberlakukan tatanan hidup baru atau yang populer dikenal dengan istilah new normal. Peran kontributif warga dalam menghadapi permasalahan Covid-19, terutama menjelang atau menyongsong eksperimentasi new normal bisa diawali dengan mengoptimalkan struktur warga. Peran fungsional warga dimasa pandemi Covid-19 adalah kemampuan mendisiplinkan seluruh perilaku anggota warganya. Mengingat kunci utama agar aman dari penularan Covid-19 adalah berperilaku disiplin. Peran strategis rukun warga untuk mendisiplinkan perilaku anggotanya dapat dipandang sebagai indikator pengukur keberhasilan warga dalam membantu pemerintah menghentikan panyebaran Covid19. Efektivitas pendisiplinan yang dilakukan rukun warga terhadap anggotanya tidak mungkin terpisahkan dari kedudukannya sebagai tokoh sentral dan panutan di dalam struktur masyarakat terkecil itu. Karena posisinya sebagai pemimpin (leader), rukun warga sebenarnya mempunyai otoritas atau kekuasaan tertinggi untuk meminta ketaatan seluruh anggota warganya supaya selalu mematuhi protokol kesehatan yang ditetapkan Pemerintah menyangkut Covid-19.

Guna melengkapi, mendukung dan mempercepat tercapainya tujuan itu, keteladanan rukun warga dalam berperilaku sehat menjadi kunci sukses atas upaya adaptif anggota warga terhadapnya. Melalui tindakannya itu rukun warga harus mencontohkan bagaimana pola perilaku hidup bersih dan sehat. Dengan keteladannya, rukun warga tidak perlu susah payah menjelaskan kepada anggota warganya mengenai pentingnya perilaku hidup bersih dan sehat. Beberapa contoh sederhana perilaku hidup sehat dan bersih yang bisa ditunjukan rukun warga, misalnya setelah selesai beraktifitas, baik itu di dalam maupun di luar rumah selalu membiasakan diri untuk mencuci tangan dengan menggunakan sabun. Berdiam diri atau tidak berpergian ke luar rumah tanpa adanya tujuan dan kepentingan yang jelas. Jika dirinya terpaksa harus meninggalkan rumah untuk keperluan yang sangat penting dan mendesak, maka sekembalinya ke rumah hendaknya langsung mandi dan mengganti pakainnya. Setelah itu baru bertemu dan bercengkerama berbagi pengalaman dengan anggota warga lainnya. Dengan keteladanan perilaku orang tua, khususnya rukun warga sebagaimana disebutkan di atas, secara tidak langsung akan mendorong anak-anaknya untuk meniru dan mengikutinya. Terlebih lagi, orang tua adalah cerminan yang bisa dilihat dan ditiru oleh anak-anaknya dalam warga (Rakhmawati, 2015). Peran kolektif warga terutama keluarga sebagai orang tua tidak mungkin bisa dipisahkan satu sama lainnya. Secara umum, peran keluarga adalah sebagai institusi pendidikan informal bagi anak- anaknya. Apalagi dengan adanya pandemi Covid-19, peran keluarga melalui didikan kedua orang tuanya tidaklah mungkin tergantikan. Meskipun ke depannya akan terjadi transformasi dan adaptasi model pendidikan warga selama pandemi Covid-19 berlangsung. Dibidang edukasi, peran keluarga adalah sebagai lembaga pendidikan utama yang di masa pandemi Covid-19 telah menggeser dan menggantikan peran vital sekolah yang dikenal luas sebagai institusi pendidikan formal. Memang sejak dahulu kala keluarga dilihat dalam perspektif pendidikan merupakan pusat pendidikan informal dan sekaligus merupakan lembaga yang pertama dan utama pendidikan anak, dimana dalam konteks ini orang tua sesunggguhnya seorang guru yang berperan mendidik anak-anaknya" (Yigibalom, 2013). Dikatakan pertama, karena jauh sebelum adanya lembaga pendidikan yang disebut sekolah, keluarga telah ada sebagai lembaga yang memainkan peran penting dalam pendidikannya sebagai peletak dasar (Supriyono, 2015). Disebut utama, karena sebagian besar dari kehidupan anak adalah di dalam keluarga, sehingga pendidikan yang paling banyak diterima oleh anak adalah di dalam keluarga (Baharun, 2016). Dengan begitu, peran praksis orang tua dalam 
menghadapi Covid-19 adalah mengedukasi atau mendidik pribadi anak-anaknya agar selalu berperilaku sesuai dengan sandar dan protokol kesehatan yang ditetapkan Pemerintah. Protokol kesehatan harus menjadi bagian dari budaya hidup bersih dan sehat. Di sinilah peran primer keluarga untuk mengarahkan dan membentuk karakter anak-anaknya dalam rangka mempersiapkannya menjalani kehidupan ditengah masyarakat. Keluarga diharapkan mampu menghasilkan anak-anak yang dapat tumbuh menjadi pribadi, serta mampu hidup di tengahtengah masyarakat. Sekaligus dapat menerima dan mewarisi nilai-nilai kehidupan dan kebudayaan (Jailani, 2014). Beberapa nilai kehidupan dan kebudayaan yang perlu diwariskan orang tua kepada anak-anaknya selama masa pandemi Covid19 ini adalah rajin-rajin mencuci tangan menggunakan sabun, jangan terlalu sering menyentuh mata, hidung, dan mulut sebelum benar-benar yakin, bahwa tangannya bersih dan terbebas dari kuman. Disamping itu, warga berperan mendidik seluruh anggotanya agar membiasakan diri menerapkan pola hidup bersih dan sehat misalnya dengan membersihkan permukaan barangbarang yang sering disentuhnya dalam kehidupan sehari-hari, menggunakan masker saat sedang sakit, termasuk ketika berada di ruang publik, membiasakan diri menutup mulut dengan menggunakan tisu atau dengan siku bagian dalam pada saat batuk dan bersin guna mencegah cairan yang keluar melalui mulut dan hidung tidak menyebar pada orang lain. Dimasa pandemi Covid-19 melalui edukasi orang tua, perilaku dan sikap mental sehat harus dapat ditularkan warga dalam membentuk kepribadian anak-anaknya. Di sini tampak jelas, bahwa warga memang memiliki peran yang sangat penting dalam pembentukan kepribadian dan mental yang sehat di dalam sebuah masyarakat (Fahrudin, 2012). Selain sebagai lembaga pendidikan, sejatinya warga masih memiliki fungsi lainnya, yaitu ekonomi. Rumah tangga adalah fungsional ekonomi-kegiatan produksi, konsumsi, dan distribusi dalam upaya memenuhi kebutuhan (Saifuddin, 2006). Dalam hal ini warga merupakan produsen dan konsumen sekaligus, dan harus mempersiapkan menyediakan atau segala kebutuhan sehari-hari seperti sandang dan pangan (Agustin, 2015). Di masa pandemi Covid-19 sekarang ini, peran penting warga sebagai lembaga ekonomi adalah lebih kepada kemampuannya dalam usaha mempersiapkan dan mencukupi kebutuhan hidup anggotanya. Keperluan hidup dalam konteks ini adalah berhubungan dengan pemenuhan aspek kebutuhan dasar manusia sebagai makhluk hidup, seperti pangan (makanan dan minum). Apalagi ditengah mengganasnya wabah Covid-19, makanan memiliki fungsi ganda, karena bukan hanya sekedar mengeyangkan perut atau menghilangkan rasa lapar, tetapi lebih kepada gizi yang terkandung di dalamnya. Disinilah peran strategis warga melalui orang tua yang harus berusaha menyediakan dan menyajikan makan-makanan sehat yang penuh gizi bagi anak-anaknya. Orang tua harus membiasakan anak-anaknya mengonsumsi makan-makanan sehat dan memperbanyak minum air putih yang terbukti memiliki beragam manfaat bagi tubuh, termasuk melindunginya dari penularan Covid-19. Jeni-jenis makanan sehat yang mengandung mengandung nutrisi lengkap dan berserat tinggi yang perlu disediakan dan dikonsumsi selama masa pandemi Covid 19, diantaranya sawi hijau, brokoli, bayam, apel, alpukat, pisang, daging, telut, susu, ikan, dan masih banyak lagi yang lainnya. Jadi selama masa pandemi Covid-19, mengonsumsi makanan tidak hanya sekedar sarana memuaskan rasa lapar. Konsumsi makanan sehari-hari harus mengandung zat gizi dalam jenis dan jumlah (porsi) yang sesuai dengan kebutuhan tubuh (Team, 2016). Apalagi gizi atau asupan makanan merupakan bagian gaya hidup sehat, karena makanan yang bergizi membantu tubuh sehat dari dalam (Hambali, 2019). Di samping itu, dalam rangka memperkuat kekebalan atau daya tahan (imun) tubuh anggota warga dari serangan Covid-19 dapat juga didukung dengan mengonsumsi vitamin. Karena kekurangan gizi pada anak, seperti kurang zat besi, vitamin atau protein yang cukup menyebabkan rendahnya daya tahan tubuh terhadap penyakit (Ayun, 2016). Karena jika kondisi tubuh dalam keadaan lemah, maka virus apapun akan lebih mudah menyusup, termasuk Covid19. Selain dengan bantuan obat-obatan kimia, minuman tradisional seperti jamu-jamuan yang sengaja diramu dan diracik secara herbal juga bisa dikonsumsi sebagai alternatif untuk memperkuat imunitas tubuh agar terhindar dari penularan Covid-19. Dimasa pandemi Covid 
19, sebaiknya setiap warga menjauhi atau menghindari makanan yang banyak mengandung gula, minuman-minuman yang tidak sehat, dan makanan cepat saji.

Pola hidup sehat sebenarnya tidak hanya berhenti pada asupan makanan yang bergizi saja, tetapi juga meliputi aktivitas fisik yang bertujuan menjaga dan memelihara kebugaran tubuh. Hal itu menjadi semakin penting berhubung lahirnya kebijakan Pemerintah yang membatasi aktivitas warganya di luar rumah. Gaya makan yang tidak teratur, ditambah lagi dengan berdiam diri di rumah seharian tanpa adanya kegiatan fisik, justru dapat membahayakan kesehatan anggota warga. Oleh karena itu, segala aktivitas jasmani tidak boleh dianggap remeh bagi kesehatan anggota warga. Melalui aktivitas jasmani akan terjadi perubahan berupa pengaruh positif terhadap kesehatan (Agus, 2010). Aktivitas jasmani dalam konteks ini adalah olahraga yang dilakukan warga secara rutin dan teratur, sehingga terlindung dari penyakit, khususnya Covid-19. Dalam situasi pandemi Covid-19, anggota warga harus rajin-rajin berolahraga, sehingga terhindar dari beragam penyakit. Berolahraga mempunyai peran besar terhadap tingkat kesehatan seseorang dan bagi yang tidak rajin berolahraga dapat mengakibatkan faktor risiko berbagai macam penyakit di masa yang akan datang (Bryantara, 2016). Tentunya tidak ada warga yang ingin terjangkit penyakit akibat malas berolahraga. Di tengah pandemi Covid-19, olahraga tampaknya kembali menjadi tren dan kebutuhan primer bagi setiap warga dalam upaya memelihara kesehatannya. Dengan adanya fenomena Covid-19, secara perlahan tetapi pasti masyarakat pun mulai menyadari arti penting olahraga bagi kesehatannya. Olahraga pada dasarnya merupakan kebutuhan setiap manusia di dalam kehidupan, agar kondisi fisik dan kesehatannya tetap terjaga dengan baik (Prasetyo, 2013). Olahraga memberikan kesempatan yang sangat ideal untuk menyalurkan tenaga dengan tujuan menuju kehidupan yang serasi, selaras, dan seimbang untuk mencapai kebahagiaan hidup yang sehat (Abdulaziz, 2016). Adapun peran warga dalam menghadapi permasalahan Covid-19 adalah dengan menanamkan kebiasaan kepada seluruh anggotanya untuk senantiasa mempraktikkan pola hidup sehat melalui kegiatan berolahraga secara rutin dan teratur dengan metode tepat. Tidak ada cara yang lebih murah dan mudah dalam menjaga kesehatan dan kebugaran tubuh dalam masa pandemi Covid-19, selain dengan olahraga yang teratur. Dengan berolahraga secara teratur merupakan satu alternatif yang efektif dan aman untuk meningkatkan atau mempertahankan kebugaran dan kesehatan jika dikerjakan secara benar (Kurnianto, 2015). Melalui berolahraga kebugaran tubuh akan tetap terjaga, sehingga Covid-19 tidak akan berani mendekat apalagi menjangkiti. Tetapi memang tidak mudah bagi seluruh anggota warga untuk membudayakan pola hidup sehat dengan berolahraga secara rutin dan teratur. Disinilah peran motivator orang tua yang harus senantiasa mendorong anak-anaknya untuk semangat berolahraga dirumah sesuai dengan kemampuan diri masing-masing. Berhubung di luar sana penularan Covid-19 masih menjadi momok menakutkan dan menghantui setiap orang. Oleh karena itu, dalam masa pandemi Covid-19, warga tidak usah jauh-jauh berolahraga apalagi sampai meninggalkan rumah. Di samping itu dalam olahraga, warga tidak perlu sampai memaksakan diri, karena justru bisa berekses negatif, yaitu menurunnya kebugaran tubuh. Olahraga yang cukup akan membantu proses regenerasi sel imun dan dapat mengurangi peradangan yang terjadi di dalam tubuh kita. Beberapa olahraga sederhana yang dapat dilakukan secara kolektif dengan warga diantaranya ialah dengan berjalan kaki mengelilingi rumah, bersepeda keliling komplek, berenang, bermain bola, dan bermain badminton. Di sinilah lingkungan warga berperan penting menciptakan budaya sehat melalui cara-cara yang sederhana tetapi efektif. Dengan demikian, lingkungan warga mempengaruhi kesehatan seseorang dalam beberapa cara (Sharma, 2013).

Selain berolahraga, peran komplimentif warga lainnya di masa pandemi Covid 19 dalam upaya menjaga kesehatan tubuh atau kesehatan fisik anggotanya adalah dengan cara memelihara kesehatan mentalnya. Hal itu selaras dengan pendapat (Sulistiowati, 2015), bahwa warga adalah bagian terkecil dari masyarakat yang berperan dalam meningkatkan kesehatan warganya untuk mencapai derajat kesehatan yang optimal baik secara fisik maupun mental. Tetapi masyarakat lebih tertarik dan condong pada kesehatan fisik, seraya memandang sebelah 
mata akan pentingnya kesehatan mental/jiwa. Padahal kesehatan mental merupakan hal penting yang harus diperhatikan selayaknya kesehatan fisik. Mengingat kondisi kestabilan kesehatan mental dan fisik saling mempengaruhi (Putri, 2015). Oleh sebab itu sudah sewajarnya kesehatan fisik maupun kesehatan mental memperoleh perhatian dan perlakuan yang seimbang dalam kehidupan warga. Warga harus memperhatikan kesehatan mental anggotanya supaya jangan sampai terlalu panik, apalagi stres akibat Covid-19. Gangguan mental terhadap anggota warga di masa pandemi ini bisa bersumber dari bahan bacaan dan tontonan berita mengenai Covid19. Kalau dibiarkan berlarut begitu saja tanpa perhatian dan penanganan yang serius kemungkinan besar menimbulkan penyakit mental kolektif. Dalam kondisi demikian itu, warga harus berusaha mengatasi dan beradaptasi terhadap situasi tersebut, sakit pada anggota warga merupakan stress situasional yang tidak diharapkan oleh warga yang dapat menyebabkan masalah kesehatan pada warga sering disebut sebagai "penyakit warga" (Ardian, 2013). Stress situasional menjadi momok paling menakutkan yang bisa merusak kesehatan mental warga berhubung volume berita Covid-19 setiap hari semakin meningkat di masyarakat. Overdosisnya peredaran imformasi Covid-19 dimasyarakat tidak jarang menyebabkan guncangan psikologis bagi anggota warga. Masalah kesehatan mental pertama yang terjadi pada warga akibat pemberitaan Covid-19 secara berlebihan adalah terjadinya penurunan kesehatan jiwa yang ditandai dengan munculnya rasa takut yang terlampau tinggi (paranoid), kecurigaan, kecemasan atau kekhawatiran berlebihan sampai mengganggu tidur dan emosionalnya. Gangguan mental seperti ini kemungkinan terjadi karena anggota warga menerima dan meresepsi pemberitaan Covid-19 yang tidak benar, sehingga melahirkan kepanikan luar biasa. Hal itu bisa menghilangkan kebahagiaan, hasrat, harapan, ketenangan, pikiran, dan kemampuan untuk merasakan ketenangan hidup, hubungan yang bersahabat dan bahkan menghilangkan keinginan menikmati kehidupan sehari-hari (Kelen, 2016).

Disinilah pemikiran kritis anggota warga sangat dibutuhkan supaya tidak mudah percaya dengan imformasi-imformasi Covid-19 yang bertebaran di media sosial. Ditengah riuhnya situasi dan kondisi akibat Covid-19, pemikiran logis dan kritis menjadi obat penenang. Karena dari berbagai imformasi yang beredar dan berkembang di masyarakat seputar Covid-19 belum tentu semuanya benar atau bisa saja berita itu hoax. Kritisisme menjadi penting karena akan menghalangi ketergesaan untuk menilai kebenaran data begitu saja, selain itu ia memberi ruang untuk memeriksa dan menolak kebohongan yang mungkin berada didalamnya (Sulaiman, Ahmad; Syakarofath, 2018). Salah satu cara membangkitkan kritisme warga adalah dengan berpegang teguh pada prinsip, bahwa imformasi resmi yang dikeluarkan Pemerintah haruslah menjadi referensi utama bagi warga dalam mencari kebenaran berita Covid-19. Mengingat kekeliruan warga dalam memainkan perannya untuk mencari, mencerna, dan mengelola imformasi Covid-19 yang berseliweran di masyarakat bisa berakibat fatal bagi kesehatan jiwa anggotanya. Padahal kondisi mental anggota warga sendiri mempunyai kedudukan vital bagi kesehatan warga secara keseluruhan. Kesehatan mental memiliki peran penting dalam upaya memperkuat imun warga untuk menangkal penularan Covid-19. Mengulang pernyataan di atas, bahwa kendala psikologis adalah salah satu akar penyebab munculnya berbagai persoalan kesehatan fisik. Orang yang mengidap gangguan psikologis rentan sekali mengalami penurunan daya tahan tubuh, sehingga gampang terserang penyakit, termasuk Covid-19. Kondisi seperti ini sangat berbahaya jika tidak segera disadari dan ditangani dengan baik oleh warga. Mengingat kesehatan mental yang timbul akibat imformasi Covid-19 yang keliru harus ditangani dengan tepat. Solusi untuk menggurangi tekanan mental berlebihan, misalnya orang tua dengan anakanaknya haruslah secara kolaboratif mencari tahu dan bertukar informasi yang akurat mengenai Covid-19. Warga harus bisa membentengi dan menghindarkan anggota warganya dari berita Covid-19 yang berdampak negatif bagi kejiwaannya. Intinya jangan mudah percaya dengan imformasi Covid-19 yang beredar luas di kalangan masyarakat tetapi belum jelas kebenarannya. Tips untuk menghindari tekanan mental secara berlebihan akibat pemberitaan Covid-19 adalah dengan melakukan aktivitas yang meredakan ketegangan, misal: olah raga, jalan-jalan, main games (Dewi, 2012). 
Peran warga lainnya yang tidak kalah pentingnya selama masa pandemi Covid-19 adalah saling memotivasi dan menguatkan satu sama lain. Peran warga saling menguatkan dalam menghadapi kondisi terburuk akibat pandemi Covid-19 akan membangkitkan semangat dan memompa optimisme. Peran motivator warga dalam situasi seperti ini dapat diwujudkan melalui interaksi sosial yang arah dan tujuannya saling mendukung. Interaksi sosial yang dipenuhi dengan dorongan moral dalam warga bisa memberi kekuatan dam motivasi positif atas musibah Covid-19 yang tengah dihadapinya. Saling menguatkan antar anggota warga itu penting sebagai wujud pertahanan diri pikiran-pikiran negatif yang dapat mempengaruhi psikis dan menurunnya imunitas tubuh. Karena jika imunitas tubuh melemah, maka virus akan lebih mudah menjangkiti, terutama dimasa pandemi Covid-19. Penguatan dalam warga memiliki peran penting di masa pandemi Covid-19. Mengingat Covid-19 bukan semata-mata hanya bencana kesehatan bagi manusia, tetapi juga berdampak negatif pada masalah ekonomi dan sosial kemasyarakatan. Permasalahan ekonomi yang muncul belakangan ini, seperti adanya keputusan merumahkan karyawan sampai pada PHK massal. Munculnya fenomena itu akibat kebijakan pemerintah yang membatasi aktivitas bagi warganya diluar rumah agar terhindar dari ancaman penularan Covid-19. Tak ayal kebijakan Pemerintah itu ikut menurunkan produktivitas perusahaan yang berdampak pada minimnya pemasukan atau keuntungan. Perusahaan pun kemudian mengeluarkan kebijakan untuk merumahkan pekerjanya. Mengingat terbatasnya kegiatan produksi dan aktivitas ekonomi di negara yang terdampak Covid-19, termasuk Indonesia, diakibatkan oleh terbatasnya pasokan barang antara dari negara lain untuk keperluan produksi, dan pembatasan aktivitas ekonomi untuk pencegahan penyebaran Covid19. Hal ini dapat menimbulkan efek rambatan pada berkurangnya permintaan tenaga kerja (Bank Indonesia, 2020). Disinilah peran warga untuk memberikan dukungan semangat atau motivasi dengan saling menguatkan dalam menghadapi pandemi Covid-19 yang tidak bisa diprediksi entah sampai kapan berakhirnya. Dukungan warga merupakan sikap, tindakan, dan penerimaan warga. Dukungan bisa berasal dari orang lain (orang tua, anak, suami, istri atau saudara) yang dekat..., dimana bentuk dukungan dapat berupa informasi, tingkah laku tertentu atau materi yang dapat menjadikan individu merasa disayangi, diperhatikan dan dicintai (Mirza, 2017). Misalnya ketika ada salah anggota warga yang terkena PHK akibat pandemi Covid-19, peran warga adalah membangkitkan motivasinya sehingga tidak larut dalam kesedihan. Bila perlu, penguatan anggota warga lainnya dapat dilakukan dengan membantunya mencari dan menemukan imformasi yang relevan sesuai kebutuhannya. Model penguatan seperti itu tentunya akan membuat yang bersangkutan merasa lebih dihargai untuk memperjuangkan masa depannya. Penguatan tersebut haruslah dilakukan melalui interaksi sosial yang yang dibangun atas dasar saling mendukung dan memotivasi satu sama lainnya. Melalui interaksi yang didasari rasa kepedulian dan cinta kasih terhadap kesulitan yang tengah dihadapi sesama anggota warga paling tidak akan merangsang dan membangkitkan motivasinya. Dukungan moral dalam bentuk interaksi sosial yang dilandasi cinta kasih, perhatian, dan rasa kasih sayang yang cukup akan membangun ketegaran dan memperkuat solidaritas antar anggota warga dalam melewati badai Covid-19. Apalagi warga itu memang terbentuk karena saling membutuhkan, sehingga mereka semua berhak mendapat penguatan dalam bentuk kasih sayang dan cinta kasih. Di sini tertanam pengertian, bahwa setiap anggota warga; suami, isteri dan anak-anak wajib dan sekaligus berhak mendapatkan kehidupan yang penuh cinta, penuh kasih sayang, dan penuh ketenteraman (Nasution, 2008). Meskipun harus disadari, bahwa tidak mudah bagi warga untuk mengekspresikan perasaan seperti itu dalam mewujudkan suasana yang nyaman dan aman. Agar sampai pada tahapan itu, warga harus mampu berperan sebagai tempat berlabuh dan berlindung bagi anggotanya untuk mengungkapkan emosinya menyangkut tekanan mental yang dialaminya akibat pandemi Covid- 19. Pengungkapan emosi dalam warga sebenarnya sangat penting bagi kondisi kejiwaan anggotanya. Karena jika individu tidak memiliki saluran untuk mengungkapkan emosinya, maka ia akan mengungkapkannya melalui sakit (Retnowati, 2003). Jadi banyak cara yang dapat digunakan untuk membangun relasi atau koneksi antar anggota warga melalui momen-momen penting sebagai bekal kehidupannya di masyarakat. Dengan 
demikian, dapat disimpulkan, bahwa anggota warga terhubung dengan cara-cara penting melalui setiap tahap kehidupan, dan hubungan ini merupakan sumber penting dari koneksi sosial..”(Thomas, 2017).

Selain yang telah disebutkan di atas, bahwa peran warga lainnya adalah dibidang sosial kemasyarakatan, baik sebelum maupun selama pandemi Covid-19 memiliki kedudukan sebagai miniatur masyarakat dalam hubungannya dengan pemenuhan aspek dasar kebutuhan manusia sebagai mahkluk sosial. Sebagai makhluk sosial, manusia perlu hidup bersama orang lain, saling bekerja sama untuk memenuhi kebutuhan dan tuntutan hidup..." (Rosmalawati, 2016). Kebutuhan dasar manusia ini semakin fundamental, karena Pemerintah telah menetapkan kebijakan physical distancing/social distancing dan pembatasan aktivitas warganya di luar rumah. Selama diterapkannya physical distancing untuk mencegah penyebaran Covid-19 ini, banyak orang diharuskan terbiasa untuk melakukan sosialisasi atau interaksi terbatas, yaitu di dalam rumah saja. Jadi peran warga dalam situasi pandemi Covid-19 adalah mengganti fungsi sosial kemasyarakatan dalam pemenuhan kebutuhan sosial manusia sebagai mahkluk sosial. Dalam kondisi seperti ini, tidak ada orang lain disekitar kita yang bisa diajak bercengkerama, selain anggota warga sendiri. Dengan begitu, orang lain yang paling dekat ditengah pandemi Covid19 adalah warga kita sendiri. Tetapi dengan berdiam diri atau mengisolasi diri di rumah, tentu menimbulkan kejenuhan dan kebosanan luar biasa bagi seluruh anggota warga. Sebenarnya beragam cara dapat dilakukan warga untuk menghilangkan perasaan bosan akibat kebijakan diam dirumah tersebut, seperti melakukan kontak secara tidak langsung melalui dunia maya. Namun terkadang, bagi beberapa orang meskipun sudah bertatap muka dengan kerabat atau warga secara virtual tetap saja terasa berbeda jika dibandingkan bertemu langsung dengan kerabat atau warga. Oleh karena itu, diperlukan interaksi sosial yang bermutu di dalam warga untuk membangun dan memperkuat keterikatan sesama anggotanya selama menghadapi wabah Covid-19. Apalagi masalah universal dalam semua warga adalah ada atau tidak adanya keterikatan yang aman di dalam warga (Jacobsen, 2004). Cara yang dapat dilakukan untuk membangun keterikatan dalam warga, seperti makan bersama secara rutin, bercengkerama mengenai pengalamannya masing-masing, bercanda gurau dan aktivitas kolektif lainnya.

Menurut Hanif (2021:33) mengatakan bahwa warga masyarakat, tokoh masyarakat, tokoh adat dan tokoh agama menggiatkan gotong royong dalam memutus rantai penyebaran Covid-19 dan membantu menangani imbas Covid-19. Kegiatan-kegiatan yang dilakukan diantaranya kerja bakti membersihkan lingkungan, penyemprotan disinfektan, menjaga lingkungan, dan pembatasan-pembatasan sosial, dan lain-lainnya. Hal tersebut dipredisposisi dari falsafah mereka bahwa manusia hidup harus beerbuat baik bagi diri sendiri, keluarga, sesama manusia, makhluk hidup dan seluruh dunia Contohnya; (1) Masyarakat Desa Sumberejo Kecamatan Madiun menyediakan sarana cuci tangan, membuat palang pintu ke wilayahnya (social distancing). Mereka melaksanakan kegiatan-kegiatan tersebut secara sukarela, baik dalam berjaga secara bergilir maupun dalam menyediakan sarana dan logistik (konsumsi), (2) Masyarakat Mejayan gotong royong mengumpulkan dana guna penyemprotan disinfektan Covid-19, (3) Forkopimda dan masyarakat membentuk "Kampung Tangguh Covid-19" diantaranya di Desa Doho Kecamatan Dagangan dan Desa Jogodayuh Kecamatan Geger (4) Masyarakat desa membentuk Satuan Tugas (Satgas) Covid-19 untuk tetap menjaga kedisiplinan, melaksanakan protokol kesehatan warga masyarakat.

\section{KESIMPULAN}

Berdasarkan pembahasan di atas, maka dapat disimpulkan, bahwa Covid-19 merupakan pneumonia baru yang muncul pertama kali di Kota Wuhan dengan karakteristik penyebarannya yang sangat cepat di berbagai belahan dunia. Karena itu dibutuhkan penanganan yang responsif dari pemerintah untuk memutus mata rantai penularannya. Seharusnya tidak hanya pemerintah saja yang berperan mengatasi persoalan akibat Covid-19, tetapi masyarakat juga harus ikut serta dan berpartisipasi di dalamnya. Warga sebagai unit terkecil dari masyarakat dapat berperan aktif dalam menghadapi persoalan Covid-19. Optimalisasi peran warga dalam menghadapi 
persoalan Covid-19 dapat dilihat dari kemampuan mendisiplinkan seluruh perilaku anggotanya, mengedukasi atau mendidik anak-anaknya supaya mematuhi protokol kesehatan yang ditetapkan Pemerintah, mempersiapkan dan memenuhi kebutuhan hidup anggotanya, menanamkan kebiasaan pada anggotanya untuk senantiasa mempraktikkan pola hidup sehat dengan berolahraga secara rutin dan teratur, memelihara kesehatan mental anggotanya, saling memotivasi dan menguatkan, sosial kemasyarakatan dalam upaya pemenuhan kebutuhan dasar manusia sebaga mahkluk sosial. Saran dalam penelitian ini adalah Pemerintah harus senantiasa mendorong dan memberdayakan institusi warga agar di masa depan lebih mengoptimalkan perannya dalam menghadapi persoalan Covid-19.

\section{DAFTAR PUSTAKA}

Abdi, M. N. (2020). Krisis Ekonomi Global dari Dampak Penyebaran Virus Corona (Covid19). AkMen Jurnal Ilmiah, 17(1), 90-98.

Almarzooq, Z. I., Lopes, M., \& Kochar, A. (2020). Virtual learning during the COVID-19 pandemic: a disruptive technology in graduate medical education.

Aziz, A. (2017). Relasi Gender Dalam Membentuk Warga Harmoni (Upaya Membentuk Warga Bahagia). Harkat: Media Komunikasi Islam Tentang Gender Dan Anak, 12(2), 27-37.

Buana, D. R. (2020). Analisis perilaku masyarakat indonesia dalam menghadapi pandemi virus corona (Covid-19) dan kiat menjaga kesejahteraan jiwa. Salam: Jurnal Sosial dan Budaya Syar-i, 7(3), 217-226.

Butar-Butar, A. J. R. (2020). Kepustakaan Medis-Pandemik di Dunia Islam. Cetakan I. Sumatera Utara: OIF UMSU.

Hanif, M. (2021). Kearifan lokal masyarakat kabupaten madiun Dalam menyikapi pandemi covid-19. Jurnal Antropologi: Isu-Isu Sosial Budaya, vol. 23 no. 01

Ichino, A., Calzolari, G., Mattozzi, A., Rustichini, A., Zanella, G., \& Anelli, M. (2020). Transition steps to stop COVID-19 without killing the world economy. VoxEU. org, 25.

Kurniawansyah, H., Amrullah, A., Salahuddin, M., Muslim, M., \& Nurhidayati, S. (2020). Konsep kebijakan strategis dalam menangani eksternalitas ekonomi dari COVID-19 pada masyarakat rentan di indonesia. Indonesian Journal of Social Sciences and Humanities, 1(2), 130-139.

Montironi, R., Cheng, L., Cimadamore, A., Lopez-Beltran, A., \& Scarpelli, M. (2020). Uropathologists during the COVID-19 pandemic: what can be learned in terms of social interaction, visibility, and social distance. European urology, 78(3), 478.

Mulyadi, M. (2020). Partisipasi Masyarakat Dalam Penanganan Penyebaran Covid-19. Info Singkat, 12(8), 13-18.

Pratiwi, D. K. (2021). Inovasi Kebijakan Pemerintah Daerah dalam Penanganan Covid-19 di Indonesia. Amnesti Jurnal Hukum, 3(1), 37-52.

Putri, R. N. (2020). Indonesia dalam menghadapi pandemi Covid-19. Jurnal Ilmiah Universitas Batanghari Jambi, 20(2), 705-709.

Santika, I. G. N. (2019). Menggali dan Menemukan Roh Pancasila Secara Kontekstual. Jawa Tengah: Lakeisha.

Sari, M., \& Wahid, A. (2020). Fenomena Penolakan Jenazah Covid-19 Perspektif Hadis di Indonesia. Mashdar: Jurnal Studi Al-Qur'an dan Hadis, 2(1), 61-76.

Sari, Y. I. (2020). Sisi terang pandemi COVID-19. Jurnal Ilmiah Hubungan Internasional, 8994.

Sugiyono. (2015). Metode Penelitian Pendidikan (Pendekatan Kuantitatif, Kualitatif, dan $R$ \& $D)$. Bandung: Alfabeta.

Sukmadinata, N. S. (2011). Metode Penelitian Pendidikan. Bandung: Remaja Rosadakarya.

Sumadi, S. (2020). Menakar Dampak Fenomena Pandemi Covid-19 Terhadap Perbankan Syariah. Jurnal Hukum Ekonomi Syariah, 3(2), 145-162. 
Vol 1. No. 4, Oktober 2021 P-ISSN : 2774-8030, e-ISSN : 2774-8030

Tuwu, D. (2020). Kebijakan pemerintah dalam penanganan pandemi Covid-19. Journal Publicuho, 3(2), 267-278. 